\title{
The D octrin to Educate Children without Violence in Islam
}

\author{
Evi Muafiah
}

Received: 20052016 / Accepted: 2505 2016 / Published online: 13122016

๑ 2016 Association of Indonesian Islamic Kindergarten Teachers Education Study Program

\begin{abstract}
Abstradt I slam was revealed to the Prophet M uhammad as rahmatan li al-'alamin of which teaches us to always love and cherish all of God's creatures, both animate and inanimate creatures. Children is God's mandate that accompanies the affection between mother and father, so they can ensure to give their children a nurturing full with love and positive affection. The atmosphere of nurturing is certainly not to be interfered with both verbal and physical violence, because these two things are very contradictory. Islam teaches us how to educate children without violence. Violence should only be done as a last resort and that too done to foster not hurt. Prophet M uhammad SAW is a role model how to educate children properly. Even when he is praying, he patiently allowing the children to ride his back when he was on prostration.
\end{abstract}

Keywords children in the perspective of the holy Koran, the characteristics and needs of children, child learning methods.

\begin{abstract}
Abstrak Islam diturunkan kepada Rasulullah Muhammad Saw sebagai rahmatan li al-‘alamin, yang di antaranya mengajarkan kita untuk selalu saling mengasihi dan menyayangi sesama makhluk Allah, baik yang hidup maupun benda mati. Anak adalah amanah Allah yang hadir menyertai kasih sayang antara ibu dan bapaknya, maka sudah sewajarnya jika kemudian orang tua mengasuhnya dalam suasan penuh kasih dan sayang. Suasana tersebut tentunya jangan sampai dicampuri dengan kekerasan baik verbal maupun fisik, karena kedua hal tersebut sangat bertentangan. Islam mengajarkan kepada kita bagaimana mendidik anak tanpa kekerasan. Kekerasan hanya boleh dilakukan sebagai alternatif terakhir dan itupun dilakukan untuk membina bukan menyakiti. Rasulullah Saw merupakan contoh bagaimana mendidik anak dengan baik. Bahkan saat shalat pun beliau dengan sabar mengasuh anak-anak dengan membiarkan punggungnya dinaiki anak-anak saat beliau sujud.
\end{abstract}

Kata kunci: anak dalam perspektif al-Qur'an, karakteristik dan kebutuhan anak, metode pembelajaran anak

\section{Pendahuluan}

A nak dan segala permasalahan yang ada di sekelilingnya adalah persoalan yang selalu muncul dari waktu ke waktu. Sebagai suatu amanah, anak adalah amanah terbesar dalam kehidupan keluarga. Adalah sebuah permasalahan tersendiri ketika sepasang suami istri yang sudah lama menjalin pernikahan tidak kunjung diamanahi anak. Permasalahan lain juga akan muncul dengan hadirnya anak yang sangat diharapkan tersebut. 
Memperlakukan anak sangat berbeda dengan memperlakukan orang dewasa. $\mathrm{Hal}$ ini terjadi karena anak adalah manusia dalam bentuk kecil yang secara agama saja belum dikenai kewajiban apapun atau biasa disebut dengan mukallaf. Jika kita memperlakukan anak sebagaimana memperlakukan orang dewasa, maka yang terjadi adalah ketidaknyamanan yang dirasakan oleh anak dan hal tersebut akan berpengaruh terhadap pertumbuhan dan perkembangannya.

Artikel ini akan memaparkan tentang bagaimana Islam mengajarkan kepada kita selaku orang dewasa dan orang tua dari para anak, untuk mendidik mereka tanpa kekerasan. M engapa harus tanpa kekerasan? Hal ini dikarenakan jika Islam mengajarkan kekerasan maka akan kontradiksi dengan tujuan datangnya Islam melalui Rasulullah M uhammad Saw, yaitu sebagai rahmatan li al-'alamin.

\section{Anak dalam Perspektif Al-Qur'an dan Hadis}

Dalam al-Qur'an, beberapa kata diterjemahkan sebagai anak. Setidaknya terdapat delapan (8) kata yang dimaknai anak, yaitu al-walad, ibnun, bintun, dzurriyyah, hafadah, al-shabiy, al-thifl dan al-ghulam. M asing-masing kata tersebut jika dikaitkan dengan kata lain akan mempunyai makna tersendiri yang menuntut sikap orang tua berinteraksi dengan anak yang dimaksud. (A bdul M ustaqim, 2006). Hal ini sangat dibenarkan karena dalam al-Qur'an tidak ada kata yang maknannya sama persis (Syahrur, 2000). Kata al-walad dalam al-Qur'an dipakai untuk menggambarkan adanya hubungan keturunan, sehingga kata walid berarti ayah kandung dan walidah berarti ibu kandung. Al-Qur'an juga menyebut anak sebagai ibnun yang bisa berarti anak kandung atau anak tiri. Dari kata ibnun tersebut juga lahir kata ya bunayya yang terulang sampai tujuh kali dalam al-Qur'an. Kata tersebut digunakan untuk memanggil anak dengan penuh kasih sayang sebagaimana dilakukan Nabi Nuh saat memanggil anaknya untuk naik perahu. Juga ketika Lukman al-Hakim menasihati anaknya agar tidak syirik kepada Allah, serta ketika Nabi Ya'kub menasehati Nabi Yusuf agar tidak menceritakan mimpinya pada saudarasaudaranya. Dari penggunaan kata ya bunayya tersebut dapat menunjukkan bahwa hendaknya antara orang tua dan anak selalu terjalin hubungan yang dibangun dalam pondasi kedekatan, mengutamakan kasih sayang dan selalu lemah lembut. Sikap yang mencerminkan kekerasan dan kebencian terhadap anak sangat bertentangan dengan al-Qur'an. Demikian pula yang telah dicontohkan dan diajarkan oleh Rasulullah Saw.

Hadis paling terkenal tentang anak adalah hadis yang menyatakan bahwa anak itu dilahirkan dalam keadaan fitrah atau suci, kedua orang tuanyalah yang sangat berperan dalam mewarnai jiwa anak, sebagaimana hadis berikut.

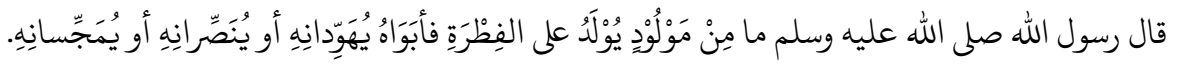

Telah bersabda Rasulullah Saw, "Setiap anak dilahirkan dalam keadaan fitrah, maka kedua orang tuanyalah yang menjadikannya Yahudi atau Nasrani atau M ajusi” (HR. M uslim).

Potensi anak yang masih suci ini akan selalu mengalami perubahan berdasarkan pembentukan dan stimulasi yang diberikan oleh orang tua dan lingkungannya. Jika sejak kecil di lingkungan tersebut sarat dengan nilai luhur agama dan tata krama, maka anak akan tumbuh menjadi pribadi tangguh dan agamis. Demikin pula sebaliknya. Anak harus dipersiapkan sedemikian rupa dengan jalan memelihara kelangsungan hidupnya tanpa harus membedakan apakah itu anak laki-laki atau anak perempuan. Karena pada dasarnya Islam justru datang untuk mengentaskan keterpurukan yang pernah dialami oleh perempuan pada masa jahiliyah 
(M ulia, 2005). Hal ini terbukti dengan adanya beberapa hadis tentang perempuan sebagaimana berikut.

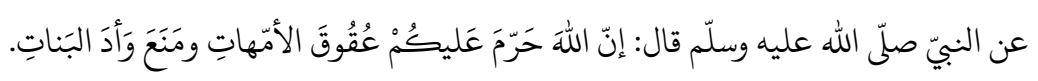

Nabi Saw bersabda, "Sesungguhnya Allah telah mengharamkan atas kamu sekalian durhaka kepada ibu dan melarang mengubur bayi perempuan." (HR. Bukhori)

Salah satu misi Rasulullah Saw diutus menjadi rasul adalah mengangkat harkat dan martabat perempuan. Beliau diutus dalam suatu kelompok masyarakat yang mempunyai tradisi sangat kejam terhadap perempuan bahkan sejak perempuan tersebut masih bayi. Mereka mengubur bayi tersebut hidup-hidup dengan beberapa alasan, antara lain: (1) Perempuan lebih banyak menjadi beban, karena fisiknya yang lemah tidak sesuai dengan budaya hidup nomaden; (2) Perempuan dianggap menjadi penyebab bertambahnya jumlah penduduk, sehingga jumlahnya harus dikurangi agar mengurangi beban secara ekonomi, politik dan sosial; dan (3) Saat terjadi perang antar suku, anak-anak dan perempuan dari pihak yang kalah akan menjadi budak pihak yang menang dan hal ini tentunya sangat menjatuhkan martabat dan kehormatan suku tersebut.

Ketiga alasan tersebut menyebabkan mereka melakukan perbuatan yang sangat tidak manusiawi terhadap anak-anak perempuan mereka. Kondisi ini diabadikan dalam al-Qur'an surat al- $\mathrm{N}$ ahl ayat 58-59. Pada ayat tersebut diceritakan bahwa mereka percaya dan menyatakan bahwa Allah punya anak padahal mereka tidak menyukai anak perempuan. Buktinya adalah apabila istri mereka melahirkan anak perempuan maka mereka menerima berita itu dengan kesal merah padam mukanya dan sangat marah. Bahkan mereka sangat malu hingga menyendiri dan berpikir akankan menanggung kehinaan ataukah menguburnya hidup-hidup? (Shihab, 2009).

Padahal bagi Rasulullah Saw, anak perempuan justru dapat menghalangi kita dari siksa neraka, jika kita berhasil mendidiknya menjadi anak shalihah, sebagaimana hadis berikut.

$$
\text { مَنْ ابتُلِيَ مِنْ هذه البناتِ بشيئ كُنْ له سِتْرا مِن النار }
$$

'Barang siapa diuji oleh perilaku anak perempuan ini, maka mereka akan menjadi penghalang baginya dari siksa neraka.” (HR. Bukhari)

\section{Karakteristik dan Kebutuhan Anak}

A nak pada hakikatnya adalah manusia yang masih kecil dan berada pada masa perkembangan untuk menjadi manusia dewasa. Dalam hal ini anak memerlukan bantuan, bimbingan dan arahan dari orang dewasa, baik itu orang tua atau pendidik dan orang dewasa lainnya yang ada di sekitar mereka. Anak mempunyai beberapa karakteristik tertentu, yaitu banyak bergerak atau tidak mau diam, suka meniru, suka menentang (membolak balikkan kata), belum bisa membedakan mana yang benar dan mana yang salah, banyak bertanya, memiliki ingatan yang tajam, menyukai dorongan semangat, suka bermain dan bergembira, suka bersaing, suka berkhayal, suka mendapatkan tantangan, suka atau penasaran dengan sesuatu yang baru serta berperasaan tajam (Nursi, 2003). M asing-masing anak mempunyai karakteristik yang berbeda antara satu dengan lainnya. $\mathrm{Hal}$ ini menuntut orang tua dan pendidik mengerti sekaligus memahami dengan benar. Masing-masing anak juga mempunyai kecerdasan yang berbedabeda, maka sebenarnya tidak ada anak yang bodoh atau nakal. A nak yang biasa kita sebut nakal sebenarnya adalah anak yang memang belum tahu mana yang benar dan mana yang salah. Anak 
yang tidak mau diam bukanlah anak nakal, tapi ia adalah anak aktif yang mempunyai kecerdasan kinestetik cukup tinggi (Suparno, 2008).

Sedangkan kebutuhan anak diantaranya adalah kebutuhan akan nutrisi serta gizi yang sehat, kebutuhan untuk membuang kotoran, pakaian, tempat tinggal yang layak, penjagaan dan pengobatan, tidur, bermain, rasa ingin tahu, rasa cinta dan kasih sayang, rasa aman, penerimaan, keberhasilan penghargaan dan kebebasan (Syaidah, 2006). Berdasarkan karakteristik dan kebutuhan anak tersebut maka muncullah hak-hak yang dimiliki oleh anak, antara lain hak anak dalam nasab, hak untuk mendapatkan gizi dan kesehatan, hak mendapatkan kasih sayang, nama baik, pengasuhan dan pendidikan.

Dari beberapa hak anak tersebut yang paling dasar adalah hak akan kasih sayang. Maka meskipun kita menganggap anak kita salah, kita tetap harus menyayanginya meskipun kondisinya memang bersalah. Kasih sayang merupakan gizi mental yang sangat penting. Anak yang hidup dalam suasana rumah tangga yang harmonis dan jarang mengalami benturan psikologis cenderung mempunyai jiwa yang positif. Ia akan menjadi anak yang optimis, periang serta tidak mudah putus asa. Sebaliknya, jika anak dibesarkan di lingkungan yang penuh dengan pertengkaran dan kekerasan, maka anak akan menjadi pribadi yang minder, kurang semangat, penakut, mudah putus asa dan bahkan suka menyendiri (M azhahiri, 2003).

Sebuah film menarik tentang perkembangan otak anak, meskipun ide tentang film tersebut penulis yakini bukan dihasilkan oleh orang muslim. Film dengan judul Inside Out yang ditulis Pete D octer ini menggambarkan betapa otak anak akan berkembang baik dalam suasana menyenangkan. Simpul-simpul otak yang dihasilkan akan hancur berantakan ketika anak mengalami kekerasan. Suasana senang dan bahagia harus selalu diupayakan agar simpul-simpul otak berkembang dengan baik. Dalam suasana belajaran pun demikian. Pembelajaran untuk anak memiliki karakteristik berupa belajar, bermain dan bernyanyi serta selalu berorientasi pada perkembangan. Pembelajaran yang dilakukan dengan menerapkan prinsip belajar, bermain dan bernyanyi dimaksudkan agar anak selalu aktif, senang dan bebas memilih. Anak belajar melalui interaksi dengan alat main dan manusia dalam suasana yang menyenangkan sehingga hasil belajarnya menjadi lebih baik. Pembelajaran yang selalu berorientasi pada perkembangan mengacu kepada usia yang tepat, individu, dan konteks sosial budaya yang tepat juga (Suryanto, 2005).

\section{Dampak Kekerasan Terhadap Tumbuh Kembang Anak}

Perlakuan keras orang tua terhadap anak pada umumnya dikaitkan dengan adanya hadis $\mathrm{N}$ abi Saw tentang diperbolehkannya memukul anak yang telah berusia 10 tahun namun belum mau melaksanakan shalat. Hadis tersebut adalah sebagai berikut:

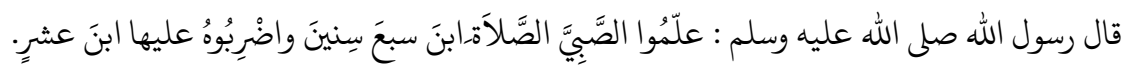

Telah bersabda Rasulullah Saw, "Ajarilah shalat anakmu yang telah berumur 7 tahun dan ketika sudah berumur 10 tahun (dia tidak mau mengerjakannya) maka pukullah dia." (HR alTurmudzi, No. 372)

Namun demikian, Rasulullah Saw justru tidak pernah memukul anggota keluarganya, istri atau pembantunya, sebagaimana hadis berikut:

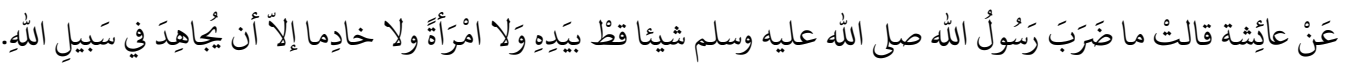

Dari 'Aisyah berkata, "Rasulullah Saw tidak pernah memukul, sekalipun kepada istri dan pembantunya, melainkan dalam kerangka jihad kepada Allah.”(HR M uslim no. 4.296) 
Bahkan beliau juga mengingatkan para sahabat agar bersikap lemah lembut kepada anggota keluarganya termasuk anak-anaknya sebagaimana hadis berikut.

$$
\text { عن عائشة قالت قال رسول الله صلى الله عليه وسلم: إنّ من أكمل المؤمنين إيمانا أجسنهم خلقا وألطفهم بأهله. }
$$

Dari 'Aisyah berkata bahwa Rasulullah Saw telah bersabda: "Sesungguhnya orang mukmin yang paling sempurna imannya adalah orang yang paling baik akhlaknya dan paling lembut dengan keluarganya." (H R al-Turmudzi no. 2.537)

Rasulullah tentunya tidak begitu saja mengajarkan kepada kita agar berlaku lemah lembut kepada siapa saja tanpa adanya hikmah di balik ajaran tersebut. Jika kita jeli, maka sebenarnya Allah melalui al-Qur'an sangat memuliakan manusia, sebagaimana tertuang dalam surat al-Isra' ayat 70 berikut.

"Dan sesungguhnya telah Kami muliakan anak cucu Adam."

$$
\text { وَلقدْْ كَرَمْنا بَنِي آدَمَ. }
$$

Pemuliaan yang dimaksud dalam ayat tersebut mencakup pemuliaan fisik, psikis, dan akal. Jika Allah saja memuliakan manusia, maka apakah kita berhak melakukan kekerasan kepada anak-anak kita? Manusia tidak akan merasa bahagia dunia akhirat sebelum ia terbebas dari penderitaan fisik, psikis, dan akal. Ia harus membebaskan fisiknya dari sakit dengan cara menjaga kesehatan serta memperhatikan asupan gizi, menjaga akal dengan cara belajar dan menjaga psikisnya dengan cara menanamkan rasa percaya diri, tenang, menyisihkan rasa takut serta membiasakan kesenangan untuk memupuk jati diri (Shihab, 2009).

Perbedaan pendapat tentang pemberian hukuman dalam mendidik anak menjadi persoalan yang sangat membimbangkan di kalangan orangtua, guru dan masyarakat. Hal ini dikarenakan hukuman juga dianggap perlu untuk menjadikan anak disiplin. Namun, hukuman identik dengan kekerasan. Dengan meniadakan hukuman bisa jadi kita telah meruntuhkan interaksi antara psikis negatif dan positif hingga anak menjadi kebal aturan. Lalu bagaimana agar kita dapat memberikan hukuman yang bijak?

Jika pemberian hukuman salah, maka yang muncul adalah kemalasan dan pembangkangan bahkan dendam. Hukuman dengan pukulan atau cacian hanyalah bagian kecil dari berbagai cara penerapan hukuman. Hukuman adalah gerbang terakhir dalam proses pembinaan. Namun dampak yang ditimbulkan sangat besar, yaitu kepribadian yang terpuruk, hidup dalam kegelisahan dan kegalauan. Hasan al-A symawi, sebagaimana dikutip Kazhim, mengatakan bahwa tongkat kayu dan ucapan yang kasar selamanya tidak akan mampu menciptakan manusia yang shalih. Justru yang tercipta adalah kera yang terlatih yang hanya mampu menunjukkan perilaku sebatas lahiriyah. Pukulan hanya boleh dilakukan sebagai alternatif terakhir dan itupun dilakukan tidak dengan dilandasi nafsu amarah, tetapi untuk pembinaan, tidak berlebihan, dan tidak menyakitkan. Sedangkan Ibnu Abdussalam mengatakan, jika ada pertanyaan, apabila anak tetap tidak bisa diperbaiki kecuali dengan pukulan yang keras, apakah masih boleh memukulnya demi mengharapkan kemaslahatan dari hal tersebut? M aka beliau menjawab, tidak boleh. Karena pukulan yang tidak menyakitkan saja sudah berbahaya, apalagi jika menyakitkan. Tidak ada yang lebih buruk dalam pembelajaran selain mengucapkan celaan dan hinaan serta pukulan secara berlebihan atau pemberian tugas yang memberatkan. $\mathrm{H}$ al tersebut hanya akan membunuh cita-cita dan semangat hidup. A palagi kekerasan hanya akan menyisakan kebencian. Target utama pendidikan anak adalah mengajari anak tanpa harus membuatnya sedih hingga meneteskan air mata (Kazhim, 2008).

Beberapa dampak buruk dari kekerasan fisik ataupun verbal antara lain sebagai berikut: 
1. M elemahkan harga diri dan mengecilkan hati. M emberikan label atau julukan, mencela, dan berkata buruk pada anak akan berakibat buruk. Dalam otak anak akan terbentuk gambaran bahwa dirinya memang seperti apa yang kita katakan. Sehingga secara tidak langsung mereka menghakimi diri sendiri dengan sifat buruk tersebut. Pikiran mereka akan mengarah pada efek negatif dan kegagalan, padahal setiap manusia pasti mempunyai kelebihan.

2. Melahirkan rasa kebencian dan tidak terima. Kecaman dan hinaan hanya akan menyisakan jurang pemisah antara orangtua dan anak atau guru dan murid. Proses pembinaan menjadi terhambat dikarenakan anak sudah menganggap kita sebagai musuhnya, bukan seseorang yang haus diambil keteladanannya. A khirnya anak akan mencari teladan lain atau panutan lain yang bisa menerima keadaannya dan ia anggap lebih cocok.

3. M engukuhkan sikap membangkang. Anak-anak yang mendapatkan pujian setelah menerima hukuman akan menganggap bahwa pujian tersebut tidak sungguh-sungguh. A kibatnya mereka tidak akan termotivasi dan merasa biasa-biasa saja.

4. Menimbulkan penyakit hati. Mayoritas kata-kata yang digunakan untuk menegur atau menghukum pastilah kata-kata yang buruk. Kata-kata buruk tersebut dapat mencemarkan pikiran dan membentuk gambaran negatif. Pada dasarnya orang tualah yang memperkenalkan kata-kata atau bahasa kepada anak. Anak tahu arti nakal juga dari orang tuanya. Dia akan menganggap dirinya nakal karena orang tuanya sering mengatainya nakal. M aka dia akan menganggap bahwa dirinya adalah anak nakal.

\section{Metode Pembelajaran Anak dalam Al-Qur'an}

Allah melalui al-Qur'an telah mengajarkan kepada kita bagaimana mendidik anak. Hal tersebut juga dicontohkan oleh Rasulullah dalam mendidik umatnya. Menurut Assegaf (2004) menyatakan ada beberapa metode pembelajaran yang dimaksud dan telah dilakukan oleh Rasulullah Saw adalah sebagai berikut:

1. Metode amaliyah atau praktik. Ajaran Islam tidak cukup disampaikan hanya dengan nasehat, melainkan memerlukan praktik yang simultan sehingga ajaran Islam tidak hanya dipahami sebagai simbol semata. A gar menjadi seorang anak yang hidup teratur, disiplin, suka menolong, mampu mengendalikan nafsu, rela berjuang untuk kemaslahatan umat dan sikap baik lainnya maka memerlukan latihan yang terus menerus sehingga inti ajaran Islam dapat tertanam secara utuh. Hal tersebut bisa diaplikasikan dengan cara rajin melakukan shalat dan puasa, baik wajib maupun sunah serta zakat dan sedekah. Hal yang tidak kalah penting adalah menumbuhkan rasa hablun min an-nas, seperti setia kawan, toleran, adil, dan peduli sesama.

2. Metode amar ma'ruf nahi munkar. Perwujudan metode ini adalah adanya penegakan aturan, tata tertib, kode etik, dan disiplin, baik itu di rumah maupun di sekolah. Orang tua atau guru hendaknya tidak menjadi pribadi yang otoriter. Segala permasalahan dapat diselesaikan dengan kepala dingin, damai, saling pengertian dan menghargai semua pihak. A turan dibuat untuk menutup kemungkinan terjadinya perbuatan munkar seperti tawuran, bolos, penggunaan narkoba, serta pornografi.

3. M etode nasihat. Agama adalah nasehat. Dapat dikatakan bahwa seluruh ajaran dalam alQur'an adalah nasihat. Al-Qur'an mencontohkan bahwa Lukman al-Hakim memberikan nasi hat kepada anak-anaknya untuk tidak menyekutukan A llah.

4. M etode kisah. Kisah, cerita atau juga dongeng adalah menuturkan sesuatu yang sarat akan pelajaran atau hikmah yang dapat dipetik kemanfaatannya. Al-Qur'an mencontohkan 
metode ini dengan memuat kisah para nabi dan umat terdahulu. Hal ini merupakan pembelajaran bagi umat setelahnya. Kisah Nabi Adam dan kedua putranya, Qabil dan $\mathrm{H}$ abil, adalah sebuah kisah yang penuh makna. Sifat hasut, dengki, dan iri yang dimiliki Q abil adalah sifat buruk yang tidak perlu ada pada diri manusia. Sebaliknya bahwa sifat kasih sayang dan toleran harus kita tebarkan seluas-luasnya di muka bumi ini.

5. M etode uswatun hasanah atau keteladanan. Al-qur'an menekankan pentingnya keteladanan dalam mendidik anak. Hal ini sangat berpengaruh bagi semuanya. Seorang ayah atau ibu di rumah yang menginginkan anaknya rajin shalat atau mengaji al-Qur'an harus memberikan contoh terlebih dahulu dengan melakukan kegiatan tersebut dengan rutin. Lambat laun anak akan melakukan karena seringnya melihat apa yang dilakukan orang tuanya. Keteladanan bagi anak dapat diperoleh tidak hanya dari orang tuanya, namun juga dapat diperoleh dari guru, masyarakat bahkan jagoan fiktif yang diidolakannya. Maka, dalam keteladanan pun bisa dimungkinkan terjadi penyesatan ketika kita salah mengambil teladan.

6. M etode hiwar atau dialog, diskusi, tanya jawab dan debat. M etode ini menunjukkan bahwa kita menghargai pendapat orang lain. Dengan metode ini kita berusaha menumbuhkan sikap kritis dan saling pengertian. Dengan saling pengertian, meskipun berbeda pendapat, kita dapat duduk berdampingan dengan rasa nyaman dan nyaman dengan siapa saja meskipun berbeda dengan kita, baik secara budaya, bahasa, ras, agama, adat, dan status sosial. Terhadap anak-anak pun kita juga harus menggunakan metode ini untuk mengetahui dan menanggapi apa yang mereka inginkan. A nak bukanlah robot yang harus mengerjakan dan menyetujui apa yang kita perintahkan tanpa diberi pengertian dan penjelasan. Dengan metode dialog ini kita akan menjadikan mereka dewasa dan bertanggungjawab.

Kiranya ajaran al-Qur'an tentang bagaimana memperlakukan anak sangat perlu untuk dicermati dan dilaksankan, sebagaimana tips prinsip dasar parenting berikut.

1. A nak-anakmu bukan pilihanmu, mereka menjadi anakmu bukan karena keinginan mereka, tetapi karena takdir Allah. (al-Q asas: 68; as-Syura: 45-50).

2. A pa yang Allah takdirkan, itulah amanah yang harus ditunaikan. (al-A nfal: 27-28).

3. Keinginan mempunyai anak adalah janji kepada Allah. Maka tepatilah janji, karena Allah akan meminta pertanggungjawaban. (al-Isra': 34; ar-Ra'd: 19-24).

4. Allah tidak membebanimu melampaui kemampuanmu, maka bersungguh-sungguhlah. (alBaqarah: 233; at-Taghabun: 16, ali-Imran: 102).

5. Allah tidak mewajibkanmu membentuk anak-anakmu mahir dalam segala hal, tetapi Allah mewajibkan membentuk mereka menjadi anak yang shalih terbebas dari neraka. (atTahrim: 6; al-A hqaf: 15).

6. Jangan berharap kebaikan dari anak-anakmu, bila tidak mendidik mereka menjadi anakanak yang shalih. (Hud: 46, M aryam: 59).

7. Jangan berharap banyak pada anak-anakmu, bila kamu tidak mendidik mereka sebagaimana mestinya. (al-Isra': 24 ).

8. Didiklah anak-anakmu sesuai fitrahnya. (ar-Rum: 30).

9. Janganlah menginginkan anak-anakmu sebagai anak-anak yang shalih sebelum engkau menjadi shalih lebih dahulu. (as-Saff: 2, at-Tahrim: 6).

10. Janganlah menuntut hakmu dari anak-anakmu, sebelum engkau memberi hak anakanakmu. (al-Baqarah: 5).

11. Janganlah menuntut hakmu dari anak-anakmu, sampai engkau memenuhi hak-hak Allah atasmu. (al-Baqarah: 63, an-Nisa': 36, al-An'am: 151, al-Isra' 23-24). 
12. Berbuat baiklah kepada anak-anakmu, bahkan sebelum mereka diciptakan. (al-Furqan: 74 , ali-Imran: 38).

13. Janganlah engkau berpikir tentang hasil akhir dari usahamu mendidik, tetapi bersungguhsungguhlah dalam mendidik. (Hud: 93).

14. Janganlah berhenti mendidik sampai kematian memisahkanmu. (al-Hijr: 99).

\section{Simpulan}

A nak adalah perhiasan sekaligus cobaan. Jika kita berhasil mendidiknya dengan baik, berarti kita telah lolos dari cobaan dan merasakan senangnya mempunyai perhiasan. Jika kita mendidik anak tersebut dengan penuh kekerasan serta aturan yang kaku, maka hal tersebut dapat melemahkan kepribadian anak sehingga anak menjadi penakut, rendah diri, pendengki bahkan pendendam. Besar kemungkinan kita akan mewariskan kekerasan kepada mereka. Tetapi jika kita terlalu memanjakan mereka, maka mereka akan menjadi generasi yang tidak mandiri, tidak percaya diri dan tidak berpendirian.

Hendaknya kita mendidik anak dengan memadukan kelembutan dan ketegasan. Tegas tidak berarti keras atau kasar. Tegas juga tidak identik dengan cacian atau hukuman fisik yang menyakitkan. Orang tua harus berusaha semaksimal mungkin agar tidak berkata kasar, berteriak dan menunjukkan kemarahan dalam bentuk cacian, bentakan atau makian yang menyakitkan hati.

\section{Referensi}

A ssegaf, A bdurahman. 2004. Pendidikan Tanpa Kekerasan. Yogyakarta: Tiara W acana.

Kazhim, Muhammad Nabil. 2008. Mendidik Anak Tanpa Kekerasan. Jakarta: Pustaka AlKautsar.

M azhahiri, Husain. 2003. Pintar M endidik Anak: Panduan Lengkap Bagi Orang Tua, Guru dan M asyarakat Berdasarkan Ajaran Islam. Jakarta: Lentera.

Mulia, Musdah. 2005. Muslimah Reformis Perempuan Pembaharu Keagamaan. Bandung: Mizan.

Mustaqim, Abdul. 2006. "Kedudukan dan Hak-hak Anak dalam Perspektif al-Qur'an", dalam Jurnal M usawa. PSW UIN Sunan Kalijaga Yogyakarta.

Nursi, M uhammad Said. 2003. Seni M endidik Anak. Jakarta: Pustaka al-Kautsar.

Shihab, Quraish. 2009. Tafsir AI-M isbah. Jakarta: Lentera H ati.

Suparno, Paul. 2008. Teori Inteligensi Ganda dan Aplikasinya di Sekolah: Cara M enerapkan Teori M ultiple Intelligences H oward Gardner. Y ogyakarta: Kanisius.

Suryadi. 2006. “Anak dalam Perspektif Hadis” dalam Jurnal M usawa, PSW UIN Sunan Kalijaga Yogyakarta.

Syahrur, M uhammad. 2000. Nahwa U shul al-Jadidah. Damaskus: A hali li al-N asyr wa al-Tawzi. Syaidah, Khasnah. 2006. "Hak Anak dalam Perspektif Islam" dalam Jurnal M usawa, PSW UIN Sunan Kalijaga Y ogyakarta. 